\title{
La relación de los contextos de aprendizaje "abierto" versus "cerrado" con las abordajes de aprendizaje de los estudiantes rurales de primer ciclo
}

\author{
António Manuel Duarte*, Ana Isa Figueira** \\ * Facultad de Psicologia. Universidad de Lisboa \\ ** Agência Nacional para a Qualificação e o Ensino Profissional, I.P.
}

\section{RESUMEN}

El objetivo de este estudio fue investigar la relación entre las "abordajes de aprendizaje" (i.e., la combinación de la motivación y las estrategias utilizadas en el aprendizaje) de los estudiantes rurales del primer ciclo de educación básica y el contexto del aula donde esto se lleva a cabo. Para la recogida de datos se llevaron a cabo entrevistas estructuradas con una muestra de los estudiantes sobre su abordaje de aprendizaje. También se caracterizaron sus ambientes de aprendizaje en el aula, a través de un cuestionario aplicado a sus propios maestros. Para una análisis general de la relación entre el contexto de aprendizaje con las abordajes de aprendizaje se llevó a cabo el teste Mann-Whitney para dos muestras independientes. En un análisis más discriminante, se calculó el coeficiente de correlación de Spearman entre los componentes particulares de esas dos variables. Los resultados apuntan a la existencia de una asociación entre una mayor exposición a un contexto de aprendizaje "abierto" (i.e., , centrado en los estudiantes) y el mayor uso por ellos de una abordaje de profundidad de aprendizaje (i.e., aprendizaje activa).

Palabras Clave: abordajes de aprendizaje; contexto de aprendizaje; educación rural; territorio rural.

\section{The relationship of "close" versus "open" learning contexts with elementary rural students' approaches to learning}

\section{ABSTRACT}

The aim of this study was to investigate the relationship between elementary rural students' "approaches to learning" (i.e., the combination of motivation and strategies used in learning) and their classrooms' learning context. A sample of elementary students participated by answering to a structured interview on approach to learning while their teachers answered to a questionnaire on classrooms' learning environment.

For a general analysis of the relationship between learning context and approaches to learning a Mann-Whitney test for two independent samples was conducted. In a more discriminated analysis, it was also calculated the Spearman correlation between particular components of those two variables. Results point to the existence of an association between a higher exposure to an "open" learning context (i.e., student centred) and higher use of a "deep" approach to learning (i.e., active learning).

Keywords: approaches to learning; learning context; rural education; rural territory.

\section{Introduction}

In the framework of educational psychology, "Student's Approaches to Learning" (SAL) theory presents an integrated view of learning, considering both the individual and the learning's context, process and product (Biggs, 1993). SAL emphasizes the role that both motivation and learning strategy play on students' performance, having empirically distinguished two main approaches to learning: "surface" and "deep" (Entwistle, Tait \& McCune, 2000). A surface approach involves an instrumental motivation (i.e., learning motivated by the need to avoid failure) and the use of a surface strategy (i.e., literal memorization). In turn, a deep approach involves an intrinsic motivational orientation (i.e., learning motivated by the pleasure it brings) and the use of a deep strategy (i.e., critical understanding of information). Research has revealed that the use of a deep approach is re- 
lated to higher levels of success and quality of learning, contrary to what happens when a surface approach is used (Asikainen, 2014; Entwistle, 1988; Entwistle et al., 2000).

Although research on approaches to learning has mainly focused on populations of higher or (less often) secondary education students, some few studies (directly or indirectly related to the SAL perspective), have also focused on elementary students, although mainly from urban territories. Some of these studies allowed to detect the existence (or at least the outline), since these phase of education, of different approaches to learning. Focusing on a sample of Brazilian students in elementary and secondary education, Gomes (2013) tested a measure that clearly distinguished the use of deep and surface approaches to learning. Other studies of the same author, with samples of students from the same population (Gomes, 2010, 2011), also differentiated four students' profiles: "deep" (high deep and reduced surface approach), "superficial" (reduced deep and high surface approach), "strategic" (high deep and surface approach) and "non-strategic" (reduced deep and surface approach).

Moreover, some of these studies also indicate the existence of significant relationships between approach to learning and learning product. The studies of Hacieminoglu (2016) and Hacieminoglu, Yilmaz-Tuzun and Ertepinar (2009), with elementary students, found a significant positive relationship between meaningful learning and academic performance which, in turn, was significantly and negatively related with literal memorization. In another study, also with elementary students, Gomes (2010) found that the deep approach correlated with higher academic performance, in contrast to what happened with the surface approach. Also in a later study with elementary students, Gomes (2013) found that the designated "deep students" had a higher academic performance than the designated "superficial students". Nevertheless, in another study, with the same population, Gomes (2011) found that the two approaches to learning didn't mutually explained students' performance: when deep approach correlated significantly with school performance the opposite didn't happened with surface approach and vice versa.

\section{The relationship of learning context with students' approaches to learning}

Research conducted in the SAL framework has revealed that higher and secondary education urban students' approaches to learning have meaningful relationships with their personal characteristics and learning environment (Biggs, 2001; Honkimäki, Tynjälä \& Valkonen 2004; Richardson, 2011). Specifically regarding the latter variable, while deep approach to learning tends to relate with a "constructivist" or "open" classroom context, characterized by students' active-participative learning construction (Biggs \& Moore, 1993), surface approach tends to relate with a "passive" or "closed" classrroom context, where knowledge is transmited unilaterally from teacher to pupil (Beyaztas \& Senemoğlu, 2015; Burnett \& Proctor, 2002).

Among the teaching practices that characterize an "open" environment are included: allowing students' freedom of choice (Ramsden, 1988); communicating clear goals and rules and providing a balanced workload (Diseth, 2007, 2013; Diseth, Pallesen, Brunborg \& Larsen, 2010; Lawless \& Richardson, 2002; Lizzio, Wilson \& Simons, 2002; Richardson \& Price, 2003; Sabzevari, Abbaszade \& Borhani, 2013); using students' language, besides discussing and questioning (Biggs \& Moore, 1993; Chen \& Dillon, 2012); explaining enthusiastically (Ramsden, 1988); relating content with personal knowledge and with outer world (Balasooriya et al., 2009;. Entwistle \& Ramsden, 1983; Ramsden, 1988); teaching learning strategies (Biggs, 1987); demonstrating trust in students' abilities (Dart \& Clarcke, 1991); helping students become aware of their personal conceptions (Svensson \& Hogfors, 1988); allowing exploration, experimentation and problem solving (Ali \& El Sebai, 2010; Beyaztaş \& Senemoğlu, 2015; Dart et al., 2002; Sadlo \& Richardson, 2003); encouraging understanding (Schmeck, 1988); engaging students in tasks that arouse curiosity (Biggs \& Kirby, 1983), an autonomous and collaborative learning (Gibbs, 1992) and reciprocal teaching (Biggs, 1990; Ramsden, $\underline{1988)}$ ); using corrective evaluation methods (Gibbs, 1992) and using open-ended responses based evaluation, as essays (Beyaztas \& Senemoğlu, 2015).

In parallel, research interested in how education is influenced by territorial context has been drawing attention to the specificity of teaching and learning in rural areas (Boix, Champollion \& Duarte, 2015). Indeed, rural schools are more likely to be isolated, to receive less support in terms of budget and technology, to have less specialized teachers and with less experience and to have a more modest offer in courses, special programs and extracurricular activities (Ballou \& Podgursky, 1995; Clopton \& Knesting, 2006; Hedges, Laine \& Greenwald, 1994; Howley \& Howley, 1995; Khattri, Rilley \& Kane, 1997; Schafft \& Jackson, 2011; Sipple \& Brent, 2008; Williams, 2010). On one hand, this schools' lack of resources can bring, especially in poorest areas, to the "mechanization" of education and therefore an emphasis on literal memorization of knowledge (Hamon \& Weeks, 2002). But then, the fact that these schools often have fewer students might promote establishment of a more significant and close teacher-student connection (Ballou \& Podgursky, 1995; Hardré, 2007), which may influence positive motivation for learning (Hardré, Sullivan \& Crowson, 2009). Some studies also indicate that, due to its specific characteristics, the rural school seems to promote "open" teaching practices (Hamon \& Weeks, 2002), such as peer tutoring, cooperative learning, interdisciplinary studies and multigrade teaching, besides teaching outside the school (Khattri et al., 1997) and exploring the environment as a learning resource (Avery, 2013; Stern, 1994 cit. Khattri et al., 1997.). Furthermore, some studies suggest that students in rural areas may experience negative conflicts and emotions regarding school, to the extent that it can compete with values considered protective of community life and family stability (Faircloth, 2009). This evidence may be related to the low value attributed to school contents, which can be perceived by students as little relevant to their professional future in rural areas. Finally, in terms of learning styles, the study of Cox, Sproles and Spreoles (1988), found that rural students show an higher preference for a more analytical, active and practical learning than students from urban areas.

Despite the existence of a relevant literature on the relationship of approaches to learning with learning context, this research framework seems to neglect elementary rural students, mainly targeting urban students of higher or secondary education.

This study therefore proposes to contribute to the knowledge of that relationship and specifically to evaluate the relationship of rural elementary students' approaches to learning with their classroom context (i.e., the teaching practices to which they are exposed). It was expected that an "open" learning context would relate positively with the adoption of a deep approach to learning and negatively with the adoption of a surface approach.

\section{Method}

Participants

A first criterion used to select the participant students was their attendance to the fourth year of the first cycle of schooling 
at a school in rural territorial context. Accordingly to the National Institute of Statistics (INE, 2014), it was considered as rural space one with a population density equal or less than 100 inhabitants per $\mathrm{km} 2$ and/or which does not include a place with a resident population equal or greater than 2,000. A second criterion for selecting the participants was the educational context to which they were exposed (i.e., 50\% from more "open" context and $50 \%$ of more "closed" context). This was implemented by considering the averages of 400 elementary teachers in two sets of items representative of "closed" and "open" context, which served as initial "pool" of the "Learning Context Questionnaire - Elementary" LCQ - E" - an instrument developed in a parallel study (Figueira \& Duarte, 2016c) and which was used in the present study, after completed and tested, to evaluate the participants' learning context (see subsection Evaluation of Learning Context) (i.e., the available teachers' higher averages to the set of items that corresponded in this "pool" to a "closed" and "open" teaching).

The samples thus include 50 students of the fourth year of Portuguese elementary rural schools. Regarding the gender 54\% are female $(n=27)$ and $46 \%$ male $(n=23)$. The average age of students is 9.3 years (range 9 to 11 years, $\mathrm{SD}=0.54$ ). The average educational attainment in the previous year (3rd year), which includes the disciplines of Mathematics, Environmental Studies and Portuguese, is 4.03 (in a scale of 1 to 5) and the standard deviation is 0.71 .

Regarding the educational level of the participants' carers, $91.26 \%$ has an elementary level of education, $44.06 \%$ has a secondary level and $14.69 \%$ has higher education.

Categorization of carers' professions followed the Portuguese Classification of Professions (INE, 2011), taking into account its ten major occupational groups besides a group corresponding to the unemployed situation. Most carers $(33.80 \%)$ are "security workers or sellers", followed by a significant number $(30.90 \%)$ of "farmers and skilled agriculture, fishing and forestry workers". Then, in descending order, $24.5 \%$ are "administrative staff", $16.5 \%$ are "technicians or intermediate level professionals", $14.6 \%$ are "installations and machines operators or assembly workers", $11.4 \%$ are "military", 30.9\% are "non qualified workers" and $9.00 \%$ are unemployed.

Participants' educational context consists of small schools, constituted by two or three classrooms with multigrade classes. These are schools with few resources with a small number of students per class (i.e., 15-20).

\section{Measuring Instruments}

\section{Evaluation of Approach to Learning}

This evaluation was made through the individual application, of a set of questions that concern approach to learning and which are contained in the "Conception of/Approach to Learning Structured Interview - Elementary - CALSI - E", developed and tested with a sample of 100 elementary students (half of rural and half of urban schools) in a parallel study (Figueira \& Duarte, 2016a). CALCI - E questions on approach to learning were grounded on categories identified by a previous qualitative study (Figueira \& Duarte, 2016b), which involved content analysis of elementary students' answers to semi-structured interview on approach to learning. Based on those categories 21 items were developed regarding three motivational orientations for learning (i.e., intrinsic, achiever and instrumental) and four learning strategies (i.e., memorizing, understanding, organizing and memorizing and understanding combined). Questions were answered through an individual orally administered structured interview, in terms of agreement or identification with them, on a Likert type scale of three points, which varies according to the question (e.g., 1 - False; 2 - Not true nor false; 3 - True). A number was registered for each answer.

For a psychometric evaluation of answers the frequency and variance of the responses to each item was analysed. This analysis kept all the items initially considered, since none was with almost any variance. A statistical analysis of answers was then conducted through an Exploratory Factor Analysis, with a factors' extraction trough main components method, followed by Varimax rotation. This analysis has highlighted ten factors with eigenvalues greater than the unit, explaining $72.78 \%$ of the variance. According to the "Scree Plot" criterion five factors were extracted that led to four scales: The first scale - "Surface Strategy" (alpha $=.59$ ) corresponds to a set of three items that seem to refer to a strategy of passive learning (close to the surface strategy), mainly oriented to memorization: (e.g., "To learn I try to memorize the content as the teachers says or it is written in the schoolbook."). The second scale - "Instrumental Motivation" (alpha $=.64$ ) consists of four items that seem to characterize a more negative motivation (close to instrumental motivation), in which learning is not internalized (e.g., "Learning tasks rob me time."). The third scale - "Extrinsic motivation 2" (alpha $=.61$ ) consists of four items that point to a motivation for learning based on avoidance of punishment (instrumental motivation) and in obtaining external reinforcement (e.g., "I learn in order to avoid punishment."; "I learn to win prizes or get good grades."). The fourth scale - "Deep Approach" (alpha = .54) refers to a more active approach to learning, where understanding and appreciation of learning are present (close to the deep approach) (e.g., "I like to perform learning tasks"; "To learn I try to understand and then memorize the material.").

\section{Evaluation of Learning Context}

This evaluation was made through the application, to the students' teachers, of the "Learning Context Questionnaire - Elementary - LCQ - E". This questionnaire was developed and tested with a sample of 400 elementary teachers (half from rural and half from urban schools) in a parallel study (Figueira \& Duarte, 2016c). The LCQ - E was built on the basis of a literature review on the relationship of the learning environment (i.e., methods and teaching practices that students are exposed), with the approaches to learning they use and focuses on six dimensions of that context: educational objectives, curricular content, teaching methods, educational measurement, educational materials \& resources and teacher-student interaction. A set of items has been developed for each dimension and items are answerable in a Likert 5-point scale (i.e., 1 - Never; 2 - Rarely; 3 - Sometimes; 4 - Often; 5 - Always). After data collection, an items' analysis was conducted, which kept all of them. From an exploratory factor analysis, through the main axe method, five factors were extracted trough the "Scree Plot" criterion. These factors explain $39.34 \%$ of the variance and gave rise to five scales. Scale 1 - "Open Context - Mixed practices", with a Cronbach's alpha of .89 and 12 items, embodies heterogeneous teaching practices that emphasize active learning characterized by students' motivation, understanding and application of knowledge, as well as continuous assessment and the establishment of a climate of trust (e.g., "I encourage my students to try to understand the contents."). Scale 2 - "Open context - Understanding and autonomy", with an alpha of .73 and 4 items, expresses practices that favour and encourage understanding (e.g., reflexivity, contents' relationship 
and discussion) and students' autonomy (e.g., "I pose reflection questions in the classroom"). Scale 3 - "Open context - Differentiation", with an alpha of .71 and 4 items, includes practices that demonstrate concern for differencing learning situations on the basis of students' freedom (e.g., "I allow students to choose learning activities."). Scale 4 - "Closed context", with an alpha of .66 and 5 items corresponds to practices that express a closed education, focused on the practice of teaching facts, emphasizing memorization and using summative evaluation (e.g., "I evaluate students through tests and final papers."). Scale 5 - "Open context - Students' specificity", possess an alpha of .57 and comprehends 3 items featuring an open-type education that includes differenced teaching practices in relation with students characteristics, including their own language, their possible special educational needs and their education level (e.g., "I differentiate the attention span depending on the type of student.").

A later second order factor analysis, conducted through the main axe method, allowed the extraction of two factors, trough the "Scree Plot" criterion, which explains

$22.87 \%$ of the variance. Factor 1, with an alpha of .68, is composed by the four subscales of "Open context": 1. "Open context - Mixed practices"; 2. "Open context -Understanding and autonomy"; 3. "Open context - Differentiation" and 5. "Open context - Students' Specificity ". This factor, which allowed the creation of an "Open Context" scale, represents a type of education characterized by practices directed toward understanding, students' autonomy and differentiation according to their specificities. For its part, factor 2 is solely composed by the scale "Open Context Understanding and autonomy."

Data collection was carried out in schools, under informed consent of the participants, their carers, teachers and institutions, with information of the study objectives, as well as the voluntary nature of participation and confidentiality of answers.

\section{Data analysis}

For the statistical analysis of data, verification of normality and homoscedasticity of the sample parameters was performed, with the result that it does not follow a normal distribution. Thus non-parametric statistical tests were used.

For an initial, more general, analysis of the relationship between approach to learning and learning context the later was dichotomized in two alternative ways: 1) "low close context" (i.e., $<$ average of scale "Close context") and "high close context" (i.e., $>=$ average scale "Close context"); 2) "low open context" (i.e., < average scale "Open context") and "high close context" (i.e., > = average scale "Open context"). Mann-Whitney test for two independent samples was then calculated twice, considering learning context as an independent variable in the two dichotomized versions (i.e., low versus high close context; low versus high open context) and the four scales of approach to learning as dependent variables.

For a second, more discriminated, analysis the relationship of approach to learning approach with more specific aspects of the learning context, the Spearman correlation coefficient was calculated between the four scales of approach to learning and the six scales of the LPQ -E (learning context).

\section{Results}

As can be seen in Table 1, there is a significantly higher value of the mean rank of Deep Approach to Learning in students of Low Close Learning Context $(\mathrm{M}=28.48)$ compared with students of High Close Learning Context $(\mathrm{M}=22.96)$.

Similarly, as can be seen in Table 2 , there is a significantly higher value of the mean rank of Deep Approach to Learning in students of High Open Learning Context $(\mathrm{M}=28.66)$ compared with students of Low Open Learning context $(\mathrm{M}=21: 48)$.

Table 1.

Approaches to Learning (mean ranks) of Low versus

High Close Learning Context's students - Sample Descriptive using Mann-Whitney test

\begin{tabular}{|c|c|c|c|c|}
\hline \multirow[t]{2}{*}{ Approach to Learning } & \multicolumn{2}{|c|}{ Close Learning Context } & \multirow[b]{2}{*}{$U$} & \multirow[b]{2}{*}{ Z } \\
\hline & Low & High & & \\
\hline Surface Strategy & 26.65 & 24.52 & 284.00 & -.86 \\
\hline Instrumental Motivation & 28.24 & 23.17 & 247.50 & -1.27 \\
\hline Extrinsic Motivation 2 & 24.01 & 26.76 & 276.50 & -.69 \\
\hline Deep Approach & 28.48 & 22.96 & 242.00 & $-2.09^{*}$ \\
\hline
\end{tabular}

$*=p<.05$

Table 2.

Approaches to Learning (mean ranks) of Low versus High Open Context's students - Sample Descriptive using Mann-Whitney test

\begin{tabular}{lcccc}
\hline Approach to Learning & \multicolumn{2}{c}{ Open Learning Context } & & \multirow{2}{*}{ Z } \\
\cline { 2 - 3 } & Low & High & & U \\
\hline Surface Strategy & 24.57 & 26.23 & 287.50 & -.67 \\
Instrumental Motivation & 25.20 & 25.73 & 301.50 & -.13 \\
Extrinsic Motivation 2 & 28.89 & 22.84 & 233.50 & -1.53 \\
Deep Approach & 21.48 & 28.66 & 219.50 & $-2.71^{*}$ \\
\hline
\end{tabular}

$*=p<.01$ 
Furthermore, as can be seen in Table 3 , the calculation of the correlation between the scales of LCQ - E (Learning Context) and the scales of the Learning Approach interview indicates the existence of significant negative correlations between several of the Open Context scales and Extrinsic Motivation scale 2. Effectively, Extrinsic motivation 2 correlates negatively and significantly with Open Context $(\mathrm{Q}=-34 ; \mathrm{p}<.05)$, with Open context - Comprehension and autonomy " $(\mathrm{Q}=-35 ; \mathrm{p}<.05)$ and with Open context - Differentiation " $(\varrho=-31 ; \mathrm{p}<.05)$.
On the other hand, there is a positive and significant correlation between the Deep Approach to Learning scale and various Open Context scales. Indeed, Deep Approach to Learning correlates positively and significantly with Open Context $(\mathrm{Q}=.39$; $\mathrm{p}$ $<.01)$, with Open context - Mixed practices $(\mathrm{\varrho}=.40 ; \mathrm{p}<.01)$, with Open context - Comprehension and autonomy " $(\mathrm{Q}=.38 ; \mathrm{p}<.01)$ and with Open context - Student's specificity" ( $\varrho=.37 ; \mathrm{p}<.01)$.

Table 3.

Correlations (Spearman coefficient) of Learning Context (LCQ $1^{\text {st }}$ c. scales) and Approach to Learning scales.

Learning Context

\begin{tabular}{|c|c|c|c|c|c|c|}
\hline Approach to Learning & $\begin{array}{l}\text { Close } \\
\text { context }\end{array}$ & Open context & $\begin{array}{l}\text { Open context - } \\
\text { Mixed practices }\end{array}$ & $\begin{array}{l}\text { Open context - } \\
\text { Comprehension } \\
\text { and autonomy }\end{array}$ & $\begin{array}{l}\text { Open context - } \\
\text { Differentiation }\end{array}$ & $\begin{array}{c}\text { Open context - } \\
\text { Student's specificity }\end{array}$ \\
\hline Surface Strategy & -.13 & .06 & .10 & .07 & -.06 & .10 \\
\hline Instrumental Motivation & -.24 & -.05 & -.02 & -.01 & -.03 & -.11 \\
\hline Extrinsic Motivation 2 & .12 & $-.34^{*}$ & -.27 & $-.35^{*}$ & $-.31^{*}$ & -.21 \\
\hline Deep approach & -.22 & $.39^{* *}$ & $.40^{* *}$ & $.38^{* *}$ & .28 & $.37^{* *}$ \\
\hline
\end{tabular}

${ }^{*} \mathrm{p}<.05{ }^{* *} \mathrm{p}<.01$

\section{Discussion and Conclusion}

This study's results regarding the relationship between elementary rural students' approaches to learning and their classroom learning context confirms the expected positive association between a more "open" (or less "closed") learning context and the tendency to use a deep approach to learning. This corroborates for rural elementary education the general notion that the deep approach to learning tends to relate with a "constructivist" classroom context (Biggs \& Moore, 1993). Specifically, the results reveal an association between students' use of such an approach and a context that, in a climate of trust, emphasizes students' motivation, understanding, knowledge application and autonomy, while assessing them continuously and differently according to their characteristics. This specifically partly corroborates for rural elementary education findings of previous studies focused on urban secondary and tertiary education (Ali \& El Sebai, 2010; Beyaztaş \& Senemoğlu, 2015; \& Kirby, 1983; Dart et al., 2002; Gibbs, 1992; Sadlo \& Richardson, 2003; Schmeck, 1988). One possible explanation for these results is that "open" teaching practices can create conditions, also in elementary rural education, that promote students' adoption of a deep approach to learning. Therefore, in an environment of relaxed learning in which the elementary student feels motivated, encouraged to understand and independently apply what is learned, continuously and constructively evaluated and respected in his or her individuality it is probably greater his or her willingness to learn on the basis of an intrinsic pleasure to learn and active involvement strategies.

In the same sense can be read the founded negative association between "open" learning context and extrinsic motivation for learning, considering the former tends to associate negatively with surface approach to learning (in which extrinsic motivation is involved). Plus, by targeting social recognition, extrinsic motivation comprehends a competitive and non cooperative vision of learning, opposed to a context that considers the student in his or her singularity (Law, 2010).

Results of this study converge therefore in direction of several other studies that relate students' centred teaching methods to their use of a deep approach to learning (Kek \& Huijer, 2011). According to these authors: "(...) when the students are in learning and teaching situations which demand higher-order levels of teaching and active learning activities and conditions, they are likely to employ deep approaches to learning." (p. 203). As posited by Biggs (1990), there might be then an adjustment effect in the sense of an alignment of students' approaches to learning with the type of teaching they are exposed to.

Nevertheless, the results don't confirm an expected positive association between a more "closed" (or less "open") learning context and the components of the surface approach to learning (i.e., surface strategy and instrumental motivation). Therefore, results don't corroborate for rural elementary education the common view that the surface approach to learning relates with a "passive" or classroom context focused on knowledge transmission and reception (Beyaztas \& Senemoğlu, 2015; Burnett \& Proctor, 2002). This might mean that in the rural elementary education environment a more "closed" learning context is "less closed" than its urban secondary and tertiary education counterparts. This hypothesis aligns with the fact that due to some specific conditions of rural schools (i.e., fewer students; multigrade classes; insertion in natural environment) rural education can involve a more significant and close teacher-student connection (Ballou \& Podgursky, 1995; Hardré, 2007) along with the use of teaching practices such as peer tutoring, cooperative learning, interdisciplinary studies and multigrade teaching, as well as teaching externally to the school (Khattri et al., 1997) and exploring the surroundings as a learning resource (Avery, 2013; Stern, 1994 cit. Khattri et al., 1997). These practices might eventually attenuate the impact of "closed" learning contexts on students' 
approaches to learning, something that would explain that those contexts do not relate here with the components of the surface approach to learning.

The present study can be seen as exploratory, as it intended to investigate a relationship of variables still almost unexplored: the one between learning environment and approaches to learning of elementary rural students. The study suggests how the learning environment can play a significant role in those approaches to learning. However, the reduced size of the sample suggests the need for further research in this area, with larger samples and more diversified elementary rural students. Moreover, the study suggests several future lines of research focused both on experimentally testing a possible causal relationship between learning context and approaches to learning; and on testing programs aimed at improving approaches to learning through changes in the learning context in elementary rural education.

Regarding the practical implications of the results, it should be noted that based on the fact that the use of a deep approach to learning is related to superior learning products (Gomes \& Mauro, 2011; Trigwell, Ellis \& Han, 2002), it is important to explore and intervene in factors that can promote that approach, from the basic levels of rural education. This study suggests that an "open" way of teaching, that actively and participatively involve students in their learning, constitute a variable that relates with (and has a possible effect on) the deep approach to learning. It is therefore important to provide elementary rural students a learning environment where they feel confident, motivated, encouraged to understand and independently apply what they learn and where they can be evaluated throughout the learning process and met in relation to their personal specificities.

\section{References}

Ali, W. G. \& El Sebai, N. A. (2010). Effect of problem-based learning on nursing students' approaches to learning and their self-directed learning abilities. International Journal of Academic Research, 4(2), 188-195.

Asikainen, H. (2014). Successful learning and studying in biosciences. Unpublished PhD thesis, University of Helsinki.

Avery, L. M. (2013). Rural science education: Valuing local knowledge. Theory into Practice, 52, 28-35.

Balasooriya, C. D., Hughes, C. \& Toohey, S. (2009). Impact of a new integrated medicine program on students'approaches to learning. Higher Education Research \& Development, 28(3), 289302, DOI: $10.1080 / 07294360902839891$

Ballou, D. \& Podgursky, M. (1995). Rural schools - fewer highly trained teachers and special programs, but better learning environment. Rural Developmental Perspectives, 10(3), 6-16.

Beyaztaş, D. \& Senemoğlu, N. (2015). Learning approaches of successful students and factors affecting their learning approaches. Education and Science, 40(179), 193-216.

Biggs, J.B. (1993). From theory to practice: A cognitive systems approach. Higher Education Research and Development, 12(1), 73-85.

Biggs, J. B. (2001). Enhancing learning: A matter of style or approach? In R.J. Sternberg \& L.F. Zhang (Eds.), Perspectives on thinking, learning and cognitive style (pp. 73-102). Mahwah, NJ: Lawrence Erlbaum Associates.

Biggs, J. B. (1987). Student approaches to learning and studying. Melbourne: ACER.

Biggs, J. B. (1990). Teaching for desired learning outcomes. In N. Entwistle (Ed.), Handbook of Educational ideas and practices (pp. 681-693). London and New York: Routledge.
Biggs, J. B. \& Kirby, J.R. (1983). Approaches to learning in Universities and CAEs. Vestes, 27(2), 3-9.

Biggs, J. B. \& Moore, P. (1993). The process of learning. New York, NY: Prentice Hall.

Boix, R., Champollion, P. \& Duarte, A. (2015). Teaching and learning in rural contexts. Sisyphus: Educational Sciences Journal, 3(2), 28-47.

Burnett, P. C. \& Proctor, R. M. (2002). Elementary School Students' Learner Self-Concept, Academic Self-Concepts and Approaches to Learning. Educational Psychology in Practice, 18(4), 325-333.

Chen, L. \& Dhillon, J. K. (2012). Deep Approaches to Learning in Improving Reading Skills: A Case Study from Yunnan Agricultural University. Theory and Practice in Language Studies, 2(8), 1603-1613.

Clopton, K. L. \& Knesting, K. (2006). Rural school psychology: Re-opening the discussion. Journal of Research in Rural Education, 21(5), 1-11.

Cox, D. E., Sproles, E. K. \& Sproles, G. B. (1988). Learning style variations between rural and urban Students. Research in $\mathrm{Ru}$ ral Education, 5(1), 27-31.

Dart, B. C. \& Clarke, J. A. (1991). Helping students become better learners: a case study in teacher education. Higher Education, 22(3), 317-35.

Dart, B. C., Burnett, P. C., Purdie, N., Boulton-Lewis, G., Campbell, J. \& Smith, D. (2000). Students' conceptions of learning, the classroom environment, and approaches to learning. Journal of Educational Research, 93(4), 262.

Diseth, A. (2007). Approaches to learning, course experience and examination grade among undergraduate psychology students: Testing of mediator effects and construct validity. Studies in Higher Education, 32, 373-388.

Diseth, A. (2013). Personality as an indirect predictor of academic achievement via student course experience and approach to learning. Social Behavior and Personality, 41(8),1297-1308.

Diseth, Å., Pallesen, S., Brunborg, G. S. \& Larsen, S. (2010). Academic achievement among first semester undergraduate psychology students: The role of course experience, effort, motives and learning strategies. Higher Education, 59, 335-352. http://doi.org/d2wnm4

Entwistle, N. J. (1988). Motivational factors in students' approaches to learning. In R.Schmeck (Ed.), Learning strategies and learning styles (pp. 21-51). N.Y.: Plenum.

Entwistle, N. J. \& Ramsden, N. (1983). Understanding student learning. London \& Camberra: Croom Helm.

Entwistle, N. J., Tait, H. \& McCune, V. (2000). Patterns of response to an approaches to stuying inventory across contrasting groups and contexts. European Journal of The Psychology of Education, 15, 33-48.

Faircloth, S. C. \& Tippeconnic, J. W. (2010). Tribally controlled colleges and universities: Global influence and local design. In K. A. Schafft \& A. Y. Jackson (Eds.). Rural education for the twenty-first century: Identity, place, and community in a globalizing world (pp.175-190). PA: The Pennsylvania University Press.

Figueira, A. I. \& Duarte, A. M. (2016a). Conceções de e abordagens à aprendizagem em estudantes do primeiro ciclo de escolaridade: relações com o contexto territorial e de aprendizagem (Elementary students' conceptions and approaches to learning: relations with territorial context and learning). Manuscript in preparation.

Figueira, A. I. \& Duarte, A. M. (2016b). Abordagens à aprendizagem em estudantes portugueses do primeiro ciclo do ensino básico (Elementary students' approaches to learning). Manuscript in preparation. 
Figueira, A. I. \& Duarte, A. M. (2016c). Desenvolvimento e testagem do "Questionário do Contexto de Aprendizagem - 10 ciclo" (Development and test of "Learning Contexts Questionnaire - Elementary"). Manuscript in preparation.

Gibbs, G. (1992). Improving the quality of student learning: theory and practice. Bristol: TES.

Gomes, C. (2010). Perfis de estudantes e a relação entre abordagens de aprendizagem e rendimento escolar (Students profiles and the relationship between approaches to learning and school performance). Psico, 40(4). 503-509.

Gomes, C. (2013). A construção de uma medida em abordagens de aprendizagem (Construction of a measure of approaches to learning). Psico,44(2), 193-203.

Gomes, A. \& Mauro, C. (2011). Abordagem Profunda e Abordagem superficial à aprendizagem: diferentes perspectivas do rendimento escolar (Deep and surface approach to learning: diferent perspectives of school performance). Psicologia: Reflexão e Crítica, 24(3), 438-447.

Hacieminoglu, E., Yilmaz-Tuzun, O., \& Ertepinar, H. (2009). Investigating elementary students' learning approaches, motivational goals, and achievement in science. Hacettepe University Journal of Education, 37, 72-83.

Hacieminoglu, E. (2016). Elementary School Students' Attitude toward Science and related variables. International Journal of Environmental \& Science Education, 11(2), 35-52.

Hamon, H. L. \& Weeks, S.G. (2002). Rural Education. In J. W. Guthrie (Ed.). Encyclopedia of Education (2nd Ed.) (pp.20832092). London: Macmillan.

Hardré, P. L. (2007). Preventing motivational dropout: A systemic analysis in four rural high schools. Leadership and Policy in Schools, 6(3), 231-265.

Hardré, P., Sullivan, D. \& Crowson, H. (2009). Student characteristics and motivation in rural high schools. Journal of Research in Rural Education, 24(16).

Hedges, L., Laine, R. \& Greenwald, R. (1994). Does money matter? A metaanalysis of studies of the effects of differential school inputs in student outcomes (an exchange: part I). Educational Researcher, 23(3), 5-14.

Honkimäki, S., Tynjälä, P. \& Valkonen, S. (2004). University students' study orientations, learning experiences and study success in innovative courses. Studies in Higher Education, 29, 431-449. http://doi.org/dk6t3q

Howley, C. \& Howley, A. (1995). The power of babble: Technology and rural education. Phi Delta Kappan, 77(2), 26-31.

INE (2011). Classificação Portuguesa das profissões 2010. Retrieved from https://www.ine.pt/xportal/xmain?xpid=INE\&xpgid=ine_publicacoes\&PUBLICACOESpub_ boui=107961853\&PUBLICACOESmodo=2\&xlang=pt on 9 of May 2016.

INE (2014). Divisão administrativa. Retrieved from https:// www.ine.pt/xportal/xmain?xpid=INE\&xpgid=ine_cont_inst\&INST=6251013 on 9 of May 2016.

Khattri, N., Riley, K.W. \& Kane, M. B. (1997). Students at risk in poor, rural areas: A review of the research. Journal of Research in Rural Education, 13(2), 79-100.

Kek, M. \& Huijser, H. (2011). Exploring the combined relationship of student and teacher factors on learning approaches and self-directed learning readiness at a Malaysian university. Studies in higher education, 36(2). 185-208.
Lawless, C. J. \& Richardson, J. T. E. (2002). Approaches to studying and perceptions of academic quality in distance education. Higher Education, 44, 257-282.

Lei, S. (2010). Intrinsic and Extrinsic Motivation: Evaluating Benefits and Drwabacks from college Instructors' Perspectives. Journal of Instructional Psychology, 37(2), 153-160.

Lichter, D. T., Roscigno, V. J. \& Condron, D. J. (2003). Rural children and youth at risk. In D. L. Brown \& L.E. Swanson (Eds.), Challenges for rural America in the twenty-first century (pp. 97-108). University Park, PA: Pennsylvania State University Press.

Lizzio, A., Wilson, K. \& Simons, R. (2002). University students' perceptions of the learning environment and academic outcomes: Implications for theory and practice. Studies in Higher Education, 27(1), 27-52. http://doi.org/b5mtx5

Ramsden, P. (1988). Context and strategy: Situational influences on learning. In R. Schmeck (Ed.), Learning strategies and learning styles (pp. 159-84). N.Y.: Plenum.

Richardson, J. T. E. (2011). Approaches to studying, conceptions of learning and learning styles in higher education. Learning and Individual differences, 21, 288-293.

Richardson, J. T. E. \& Price, L. (2003). Approaches to studying and perceptions of academic quality in electronically delivered courses. British Journal of Educational Technology, 34, 4556. http://doi.org/cjgzd8

Rodrigues, M.(2010). As tecnologias de informação e comunicação e a escola em meio rural (Information and communication technologies and the school). Mediações,1(2), 88-102.

Sabzevari, S.; Abbaszade, A. \& Borhani, F. (2013). The assessment methods and learning approaches in nursing students of Kerman University of Medical Sciences in Iran. Creative Education, 40(2), 160-164.

Sadlo, G. \& Richardson, J. T. E. (2003). Approaches to studying and perceptions of the academic environment in students following problem-based and subject-based curricula. Higher Education Research and Development, 22, 253-274.

Schafft, K.A. \& Jackson, A. (Eds.) (2011). Rural education for the twenty-first century: Identity, place, and community in a globalizing world. University Park, PA: Penn State University Press.

Schmeck, R. (1988). Strategies and styles of learning - An integration of varied perspectives. In R. Schmeck (Ed.), Learning strategies and learning styles (pp. 317-347). N.Y.: Plenum.

Sipple, J. W. \& Brent, B. O. (2008). Challenges and opportunities associated with rural school settings. In H.F. Ladd \& E.B. Fiske (Eds.), Handbook of research in education finance and policy (pp. 612-629). New York: Routledge.

Svensson, L. \& Högfors, C. (1988). Conceptions as the content of teaching: Improving education in mechanics. In P. Ramsden (Ed.) Improving learning: new perspectives (pp. 162-167). London: Kogan Page.

Trigwell, K., Ellis, R. A. \& Han, F. (2012).Relations between students'approaches to learning experienced emotions and outcomes of learning. Studies in Higher Education, 37(7), 811-824.

Williams, D. T. (2010). The rural solution: How community schools can reinvigorate rural education. Washington: Center for American Progress. Retrieved from from http://www. ruraledu.org/user_uploads/file/The_Rural_Solution.pdf on 18 February 2015. 
